\title{
A family cluster of Chagas disease detected through selective screening of blood donors: A case report and brief review
}

\author{
Guillaume Mongeau-Martin DCS ${ }^{1}$, Momar Ndao DVM PhD ${ }^{1,2}$, Michael Libman MDCM ${ }^{1}$, \\ Gilles Delage $\mathrm{MD}^{3}$, Brian J Ward MSc, MDCM ${ }^{1,2}$
}

\begin{abstract}
G Mongeau-Martin, M Ndao, M Libman, G Delage, BJ Ward. A family cluster of Chagas disease detected through selective screening of blood donors: Case report and brief review. Can J Infect Dis Med Microbiol 2015;26(3):157-161.
\end{abstract}

Chagas disease (CD) is a protozoan infection caused by Trypanosoma cruzi, which is transmitted by triatomine insect vectors in parts of Latin America. In a nonendemic country, such as Canada, spread can still occur via vertical transmission, and infected blood or organ donations. The Canadian Blood Services and Héma-Québec have both implemented selective screening of blood donors for CD based on risk factors. In 2011, Héma-Québec identified two seropositive 'at-risk' Chilean siblings who had donated blood in Montreal, Quebec. They were referred to the JD MacLean Centre for Tropical Diseases (Montreal, Quebec) for confirmatory testing (T cruzi excreted-secreted antigen ELISA, polymerase chain reaction and/or radioimmunoprecipitation assay) and follow-up. Screening of the rest of the family revealed two other seropositive family members (the mother and sister). While their geographical history in Chile suggests vectorial transmission, this family cluster of $\mathrm{CD}$ raises the possibility of vertical transmission. Congenital infection should always be considered among CD-positive mothers and pregnant women. With blood donor screening, Canadian physicians will increasingly see patients with $\mathrm{CD}$ and should know how to manage them appropriately. In addition to the case presentation, the authors review the transmission, screening and clinical management of $\mathrm{CD}$ in a nonendemic context.

Key Words: Blood donor screening; Chagas disease; ELISA; PCR; RIPA; Vertical transmission

$\mathrm{C}$ hagas disease $(\mathrm{CD})$ is a zoonotic disease caused by Trypanosoma cruzi, a protozoan parasite that is endemic in parts of Mexico, Central and South America (1). It is transmitted by triatomine insect vectors, members of the Reduviidae family. CD can also be spread by congenital transmission from mother to fetus, by blood transfusion or organ transplantation and, more rarely, by consumption of food contaminated with $T$ cruzi (2).

Most individuals infected by $T$ cruzi experience a nonspecific acute phase with influenza-like symptoms. After one to two months, infected individuals typically enter an asymptomatic, chronic phase referred to as the indeterminate form of CD (3). While most infected individuals remain asymptomatic their entire lives, 20\% to $30 \%$ develop cardiac or gastrointestinal (GI) complications over the

\section{Une grappe familiale de maladie de Chagas décelée grâce au dépistage sélectif des donneurs de sang : rapport de cas et brève analyse}

La maladie de Chagas (MC) est une infection protozoaire causée par le Trypanosoma cruzi, transmis par des vecteurs d'insectes du genre triatomine dans certaines régions d'Amérique latine. Dans un pays non endémique comme le Canada, la propagation est possible par transmission verticale et par les dons de sang ou d'organes infectés. La Société canadienne du sang et Héma-Québec ont tous deux adopté le dépistage sélectif des donneurs de sang pour déceler la MC en fonction des facteurs de risque. En 2011, Héma-Québec a repéré deux membres d'une fratrie chilienne séropositifs « à risque » qui avaient donné du sang à Montréal, au Québec. Ils ont été orientés vers le Centre des maladies tropicales JD MacLean de Montréal pour subir des tests de confirmation (test ELISA des antigènes excrétés-sécrétés par T cruzi, réaction en chaîne de la polymérase ou test de radio-immunoprécipitation) et profiter d'un suivi. Le dépistage du reste de la famille a révélé deux autres membres séropositifs (la mère et la sœur). Étant donné leur origine géographique, on pourrait subodorer une transmission vectorielle, mais la grappe familiale de MC soulève la possibilité d'une transmission verticale. L'infection congénitale devrait toujours être envisagée chez les mères et les femmes enceintes positives à la MC. Grâce au dépistage des donneurs de sang, les médecins canadiens verront de plus en plus de patients atteints de la MC. Ils devraient donc savoir comment la prendre en charge correctement. En plus de la présentation de cas, les auteurs passent en revue la transmission, le dépistage et la prise en charge clinique de la $\mathrm{MC}$ dans un contexte non endémique.

${ }^{1} J D$ MacLean Tropical Diseases Centre; ${ }^{2}$ National Reference Centre for Parasitology, Research Institute of the McGill University Health Centre,

Montreal; ${ }^{3}$ Héma-Québec Inc, Ville Saint-Laurent, Quebec

Correspondence: Dr Brian J Ward, Tropical Diseases Centre, Montreal General Hospital, 1650 Cedar Avenue, Room L10-509, Montreal,

Quebec H3G 1A4. Telephone 514-934-1934 ext 42810, fax 514-934-8224, e-mail brian.ward@mcgill.ca

course of several decades (2). Acute CD is relatively simple to diagnose by microscopy of whole anticoagulated blood or polymerase chain reaction (PCR) to detect the presence of $T$ cruzi DNA in the blood. During the chronic phase, the parasitemia is low and intermittent, and diagnosis relies on serological methods (eg, ELISA, indirect fluorescent antibody test, radioimmunoprecipitation assay [RIPA]) (4,5).

In nonendemic countries such as Canada, CD is mainly diagnosed among Latin American migrants (6). Based on the large Latin American immigrant population in the United States, it is estimated that $>300,000$ Americans have CD (7). In Canada, the demographics are very different, with an estimated 5553 infected immigrants residing in the country in 2010 (6). Limited spread of CD can still 


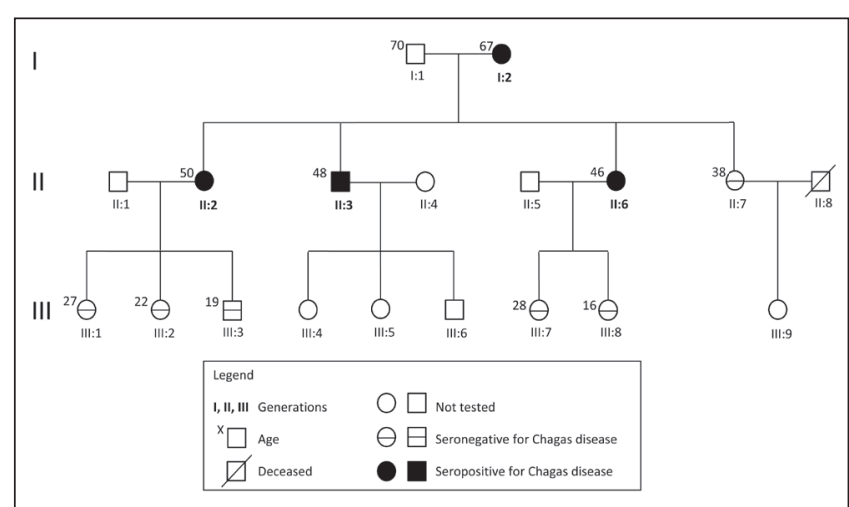

Figure 1) Genogram of the family

occur in nonendemic countries through congenital transmission and via infected blood and organ donations. Although only a small number of cases of blood-transmitted CD have been reported in North America over the past 26 years (two in Canada [8,9]), these documented cases are likely to represent the tip of the iceberg because most such infections would be asymptomatic and go undiagnosed.

In May 2010, the Canadian Blood Services (CBS), which provides transfusion services for all provinces except Quebec, implemented selective screening of blood donors for CD using the Abbott PRISM Chagas Assay (a chemiluminescent immunoassay; Abbott Laboratories, USA) (10). Details of this screening program have been described recently (11). As of early 2013, CBS had screened $>27,000$ 'at-risk' donors (based on travel, residence and maternal ancestry) and $>80,000$ 'no risk' donors, and identified 14 seropositive subjects in the first group $(0.05 \%)$ and one seropositive subject in the second group $(0.001 \%)$ (12). A similar program had been implemented in March 2009 by Héma-Québec, the provider of transfusion services in that province (13) (www.hema-quebec.qc.ca). As of October 2013, 11,730 at-risk donors have been tested by HémaQuébec, and four confirmed positive donors have been found ( $\mathrm{Dr}$ Gilles Delage, Héma-Québec, personal communication). In July 2011, this program identified two seropositive 'at-risk' Chilean siblings who had donated blood in Montreal, Quebec. These siblings are part of the family of Chilean immigrants that is the focus of the present article.

\section{CASE PRESENTATION}

In 2011, the two siblings, II:3 and II:6 (48 and 46 years of age, respectively [Figure 1]), donated blood at a Héma-Québec clinic. On their donor questionnaires, they both answered affirmatively to all three of the CD 'at-risk' questions: they were born in Chile to a Chilean mother and had lived in Chile for many years (17 and 15 years, respectively, before emigrating to Canada). Initial screening by Héma-Québec (PRISM Chagas Assay, Abbott) suggested that they were both seropositive, and their status was confirmed by repeat testing using the same assay. They were referred to the JD MacLean Centre for Tropical Diseases at the McGill University Health Centre (Montreal, Quebec) for assessment. Blood was drawn for confirmatory serological testing using a T cruzi excreted-secreted antigen ELISA (TESA-ELISA) $(14,15)$ and PCR by the National Reference Centre for Parasitology (NRCP) in Montreal. Some samples were also tested using RIPA by Quest Diagnostics (USA). Neither had any cardiac nor GI symptoms, and physical examinations were normal. The brother's (II:3) electrocardiogram (ECG) showed sinus bradycardia, but was otherwise normal. His sister (II:6) had an abnormal ECG with sinus bradycardia and nonspecific $\mathrm{T}$ wave changes. Their echocardiograms were both normal. They were asked to bring their parents (I:1, I:2) and their two other sisters (II:2, II:7) to the clinic to be tested for CD.
TABLE 1

Test results for first and second generations

\begin{tabular}{|c|c|c|c|c|}
\hline $\begin{array}{l}\text { Family } \\
\text { member }\end{array}$ & $\begin{array}{l}\text { Serological } \\
\text { testing }\end{array}$ & PCR & Electrocardiogram & $\begin{array}{c}\text { Echo- } \\
\text { cardiogram }\end{array}$ \\
\hline $1: 2$ & NRCP TESA + & - & $\begin{array}{l}\text { Abnormal: right bundle } \\
\text { branch block, prolonged } \\
\text { QRS and incomplete left } \\
\text { posterior fascicular block }\end{array}$ & Normal \\
\hline$\|: 2$ & NRCP TESA + & - & $\begin{array}{l}\text { Rightward axis, otherwise } \\
\text { normal }\end{array}$ & Normal \\
\hline$\| 113$ & $\begin{array}{l}\text { Abbott PRISM }{ }^{\circledR}+ \\
\text { NRCP TESA + } \\
\text { RIPA + }\end{array}$ & - & $\begin{array}{l}\text { Sinus bradycardia, } \\
\text { otherwise normal }\end{array}$ & Normal \\
\hline ॥l:6 & $\begin{array}{l}\text { Abbott PRISM }{ }^{\circledR}+ \\
\text { NRCP TESA + } \\
\text { RIPA + }\end{array}$ & - & $\begin{array}{l}\text { Abnormal: sinus bradycardia } \\
\text { and nonspecific T wave } \\
\text { abnormality }\end{array}$ & Normal \\
\hline$\|: 7$ & NRCP TESA - & - & Normal & Normal \\
\hline
\end{tabular}

+ Positive; - Negative; NRCP National Reference Centre for Parasitology; PCR Polymerase chain reaction; RIPA Radioimmunoprecipitation assay; TESA Trypanosoma cruzi excreted-secreted antigens

Their mother (I:2, 67 years of age) and sisters (II:2 and II:7, 50 and 38 years of age, respectively) were tested using TESA-ELISA and PCR at the NRCP. The father (I:1, 70 years of age) declined to be tested. The eldest daughter (II:2) had no cardiac symptoms, although she had noted mild, intermittent diarrhea and abdominal cramps for the past three years. Neither the mother (I:2) nor the youngest sister (II:7) had any cardiac or GI complaints and their physical examinations were entirely normal. The mother's ECG was abnormal, with a right bundle branch block, a prolonged QRS and incomplete left posterior fascicular block. The eldest sister (II:2) had rightward axis deviation with an otherwise normal ECG. The youngest sister's (II:7) ECG was normal. Cardiac ultrasounds for these three members of the family (I:1, II:2 and II:7) were all essentially normal.

A summary of test results for the first and second generations is presented in Table 1 . Four of the five family members tested were found to be positive by $\geq 1$ of the serological assays. Only the youngest sister (II:7) was found to be seronegative for CD. PCR testing was negative for all four of the seropositive family members.

Because CD can be transmitted congenitally, the two CD-positive sisters (II:2, II:6) were advised to bring their five children to the Tropical Diseases Centre for testing (III:1-3 and III:7-8). All were found to be seronegative.

\section{DISCUSSION}

A family with four CD-positive individuals is a rare finding in a nonendemic country such as Canada. However, with the introduction of a screening program for blood donors, Canadian physicians will likely encounter an increasing number of newly diagnosed CD patients and will have to educate and manage these patients appropriately. The present case provides a good opportunity to review and discuss issues related to $\mathrm{CD}$ diagnosis and treatment.

\section{Transmission}

This family cluster raises important questions about when and how they became infected. Individual infection (via the triatomine vector), congenital infection, oral infection (eg, contaminated food) and transfusion/transplantation all need to be considered. In these cases, none of those infected had a history of either transfusion or organ transplant.

The fact that the mother (I:2) of three of the CD-positive children (II:2, II:3, II:6) was seropositive raises the possibility of congenital transmission. Because maternal-fetal transmission rates are only $5 \%$ to $6 \%(16,17)$, it is unlikely that all three were vertically infected. However, the degree to which the parasite is controlled by the mother can have a powerful influence on the likelihood of transmission through 


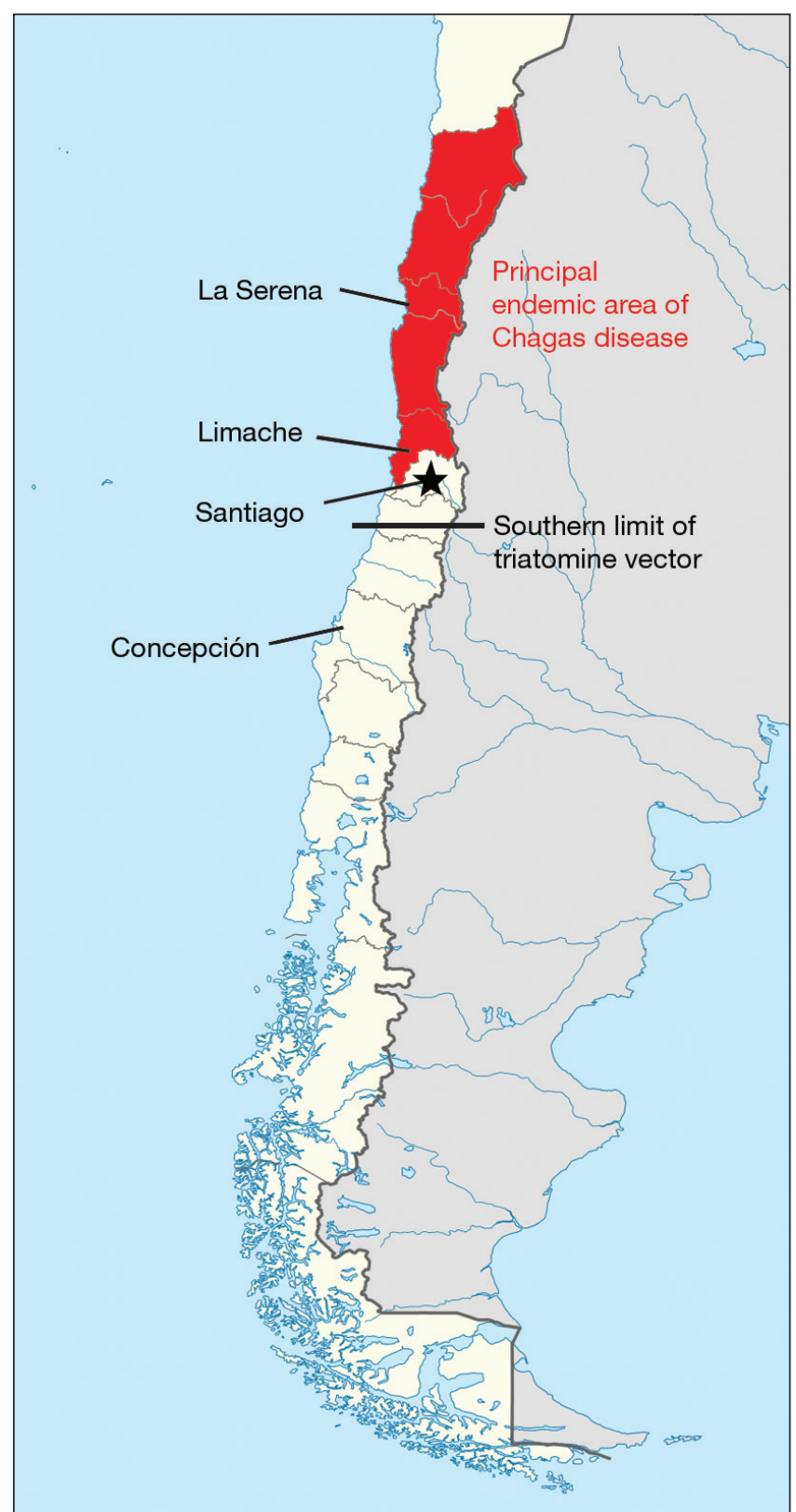

Figure 2) Chile: Principal endemic area of Chagas disease in the middle of the 20th century $(19,21)$. Produced using a blank map found on Wikimedia Commons (http://commons.wikimedia.org/wiki/File:Chile_ location_map.svg).

the placenta (17). Family clusters of congenital infection have been reported in the Southern Cone region of South America (18). Although the matriarch in the family cluster (I:2) was PCR-negative at 67 years of age, we do not know the level of parasitemia during each of her pregnancies.

This family's geographical history is useful in determining the relative risk of individual versus congenital infection (Figure 2). The parents (I:1, I:2) and their children (II:2, II:3, II:6, II:7) were all born in Chile. The mother (I:2) was born in 1944 in Limache, a small town north of Santiago. The father (I:1) was born in 1941 in La Serena, and moved to Limache when he married I:2 in 1960. Their first two children (II:2, II:3) were born in Limache in 1961 and 1962, respectively. In 1964, the family moved to Concepción, a larger city south of Santiago, where the two youngest children (II:6, II:7) were born (1964 and 1973, respectively). After the Chilean political turmoil in 1973, the family was separated: the oldest siblings (II:2, II:3) moved north to La Serena, the mother (I:2) left for Santiago with her youngest daughter (II:7), and her other daughter (II:6) moved to Limache. Finally, in 1979, the entire family emigrated to the province of Quebec, where they currently reside.

Based on this history, it is plausible that the matriarch (I:2) and the three positive children (II:2, II:3, II:6) contracted CD by vectorial transmission in Limache, which was a small municipality in Valparaíso, one of the principal CD-endemic regions of Chile in the mid-20th century (19) (Figure 2). Housing quality is an important risk factor for triatomine infestation (eg, cane/thatch roofs, adobe/stone walls, poor ventilation) (20) and the family described their home as a rudimentary 'country house'. However, these three children lived in Limache for only short periods of time ( $<3$ years for II:2 and II:3 and six years for II:6), which narrows the time frame for vectorial transmission. Vectorial infection in La Serena is another possibility for II:2 and II:3, who lived in this small town for six years after the 1973 political crisis. In both of these smaller, rural communities, oral infection by contaminated food, juice or water may also have occurred. The only uninfected child in the second generation (II:7) was born in Concepción, which is below the southern limit of the geographical distribution of the triatomine vector in Chile (21), and lived only in Concepción and Santiago.

\section{Screening}

This family cluster illustrates the potential impact of screening programs for T cruzi infection. Not only did it prevent the introduction of potentially contaminated blood into the blood pool, it also led to the diagnosis of CD in two additional family members (I:2, II:2). At the time of writing, the CBS selective screening program had identified $15 \mathrm{~T}$ cruzi antibody-positive donors in the first three years of operation (12). Whether selective screening based on risk factors is sufficient to prevent the introduction of blood products contaminated with T cruzi into the blood pool is a legitimate concern. Alternative and more comprehensive approaches include universal testing (every donor, every donation) and screening at the first interaction with blood services (so-called 'screening in') with subsequent rescreening based on new risks (eg, travel or residence in CD-endemic areas). A recent serosurvey involving $>84,000$ subjects who answered 'no' to all of the 'risk questions' found only one CD-positive individual $(12,22)$, demonstrating that selective screening programs will only miss a very small number of cases in Canada. Vertical transmission of CD in nonendemic countries, such as Canada (11), Switzerland (23) and Spain (24), can occur and be undetected in the absence of selective prenatal screening. Although a screening program for pregnant women could theoretically identify candidates for serological screening, such a program would be cumbersome and very low yield. However, such a program would permit newborns of seropositive mothers to be tested at birth by PCR and/or microscopy of cord/venous blood (25) or by serology at eight to 10 months of age, after maternal antibodies are no longer present (26). CD can usually be successfully treated in infants (refer to Treatment section). Fortunately, none of the five children in the third generation of our family cluster were found to be CD positive.

\section{Evaluation of patients diagnosed with $\mathrm{CD}$}

Subjects identified in screening programs (eg, blood bank, possibly prenatal care) first need to have the diagnosis confirmed using one or more reference tests (eg, TESA-ELISA, RIPA, PCR). Although there is no 'gold standard' assay, several such tests are available through the NRCP (www.nrcp.ca) in Canada or through other reference laboratories (eg, Centers for Disease Control and Prevention, www.cdc.gov). It is generally appropriate to screen the siblings and parents of any CD-positive subject as well as the children of infected mothers. A complete medical history and a physical examination should be performed, with a focus on signs and symptoms suggestive of cardiac or GI manifestations. Recommended testing includes a 12-lead ECG in all CD-positive patients (27). An echocardiogram 
can also be performed, especially if there are worrisome cardiac symptoms (eg, palpitations, chest pain) or conduction defects. CD-positive subjects with GI complaints can be assessed with barium studies and/or endoscopy. Asymptomatic patients should be followed up on an annual basis to identify new symptoms and to repeat an ECG and/or echocardiogram. At the time of writing, the four CD-positive subjects in this family cluster have been followed for approximately three years with no evidence of new or progressive cardiac or GI symptoms/abnormalities.

\section{Treatment}

Benznidazole and nifurtimox are currently the only antitrypanosomal drugs used to treat CD. Both are reasonably effective in acute $(\geq 60 \%)$ and congenital infections (approximately 100\%) (25,28,29). However, both are associated with significant side effects (30). Although success rates fall dramatically after one year of age in congenital disease, treatment with one of these drugs is still recommended for all individuals $<18$ years of age in the chronic phase (27). While there is no compelling evidence for treatment in adults between 18 and 50 years of age with chronic CD, the results of several small observational studies (reviewed in Viotti et al [31]) suggest that benznidazole can slow the progression of cardiac disease. As a result, a consensus is growing that treatment should at least be offered to all CD patients between 18 and 50 years of age (32). The question of whether benznidazole can slow or prevent progression of CD cardiomyopathy is currently being evaluated in a large, randomized,

\section{REFERENCES}

1. Coura JR, Borges-Pereira J. Chagas disease: 100 years after its discovery. A systemic review. Acta Trop 2010;115:5-13.

2. Shikanai-Yasuda MA, Carvalho NB. Oral transmission of Chagas disease. Clin Infect Dis 2012;54:845-52.

3. Andrade JP, Marin Neto JA, et al. I Latin American Guidelines for the diagnosis and treatment of Chagas' heart disease: Executive summary. Arq Bras Cardiol 2011;96:434-42.

4. WHO Expert Committee. Control of Chagas disease. Brasilia: World Health Organization, 2002. World Health Organ Tech Rep Ser 905.

5. Otani MM, Vinelli E, Kirchhoff LV, et al. WHO comparative evaluation of serologic assays for Chagas disease. Transfusion 2009;49:1076-82.

6. Schmunis GA, Yadon ZE. Chagas disease: A Latin American health problem becoming a world health problem. Acta Trop 2010;115:14-21.

7. Bern C, Montgomery SP. An estimate of the burden of Chagas disease in the United States. Clin Infect Dis 2009;49:e52-4.

8. Nickerson P, Orr P, Schroeder ML, Sekla L, Johnston JB. Transfusion-associated Trypanosoma cruzi infection in a non-endemic area. Ann Intern Med 1989;111:851-3.

9. Lane DJ, Sher G, Ward B, Ndao M, Leiby D, Hewlett B. Investigation of the second case of transfusion transmitted Chagas' disease in Canada. San Francisco: 42nd Annual Meeting of the American Society of Hematology, December 1 to 5, 2000.

10. Canadian Blood Services. Implementation of selective Chagas disease (Trypanosoma cruzi) antibody testing for at-risk blood donors. < http://www.transfusionmedicine.ca/sites/ transfusionmedicine/files/news/2010_Notice_CMAJ.pdf> (Accessed October 20, 2013).

11. O'Brien SF, Scalia V, Goldman M, et al. Selective testing for Trypanosoma cruzi: The first year after implementation at Canadian Blood Services. Transfusion 2013;53:1706-13.

12. O'Brien SF, Scalia V, Goldman M, et al. Evaluation of selective screening of donors for antibody to Trypanosoma cruzi: seroprevalence of donors who answer "no" to risk questions. Transfusion 2014;54:863-9.

13. Hema-Québec. Chagas Disease - New selection criterion concerning Chagas disease. <www.hema-quebec.qc.ca/donner/donde-sang/qui-peut-donner-du-sang/maladie-de-chagas.en.html> (Accessed October 20, 2013).

14. Ndao M, Spithill TW, Caffrey R, et al. Identification of novel diagnostic serum biomarkers for Chagas' disease in asymptomatic subjects by mass spectrometric profiling. J Clin Microbiol 2010;48:1139-49. multinational study, Benznidazole Evaluation for Interrupting Trypanosomiasis (BENEFIT) (33). Results from this trial should be available sometime in 2015. Because toxicity with either benznidazole or nifurtimox can be severe and tends to increase in older individuals (30), the risk:benefit ratio of treatment worsens with age $(27,31,32)$. As a result, there are no clear treatment guidelines for any of the 46- to 67 -year-old adult patients in our family cluster, particularly for subjects I:2 and II:6, who have abnormal ECGs but normal echocardiograms. After discussion of the pros and cons of therapy, all four decided not to initiate treatment until the results of the BENEFIT trial are known. Although there was considerable optimism that posaconazole may be a less toxic alternative therapy, the results of a recent randomized, controlled trial versus benznidazole are not encouraging (34). New drugs with greater efficacy in the chronic phase of $\mathrm{CD}$ are urgently needed.

\section{CONCLUSION}

The present report describes an unusual family cluster of CD and illustrates the importance of screening 'at-risk' blood donors. Not only did this program prevent the entry of contaminated blood into the blood system, it also led to the diagnosis of CD in two other members of this family. Vertical transmission should always be considered when dealing with CD-positive mothers and, especially, pregnant women, because at-risk newborns and infants can be tested and successfully treated if found to be positive.
15. Berrizbeitia M, Figueroa M, Ward BJ, et al. Development and application of an ELISA assay using excretion/secretion proteins from epimastigote forms of T. cruzi (ESEA antigens) for the diagnosis of Chagas disease. J Trop Med 2012;2012:875909.

16. Torrico F, Alonso-Vega C, Suarez E, et al. Maternal Trypanosoma cruzi infection, pregnancy outcome, morbidity, and mortality of congenitally infected and non-infected newborns in Bolivia. Am J Trop Med Hyg 2004;70:201-9.

17. Apt W, Zulantay I, Arnello M, et al. Congenital infection by Trypanosoma cruzi in an endemic area of Chile: A multidisciplinary study. Trans R Soc Trop Med Hyg 2013;107:98-104.

18. Sánchez Negrette O, Mora MC, Basombrío MA. High prevalence of congenital Trypanosoma cruzi infection and family clustering in Salta, Argentina. Pediatrics 2005;115:e668-72.

19. Schofield CJ, Apt W, Miles MA. The ecology of Chagas disease in Chile. Ecol Dis 1982;1:117-29.

20. Schenone H, Villarroel F, Alfaro E. [Epidemiology of Chagas disease in Chile. Housing conditions related to the presence of Triatoma infestans and the rate of humans and animals infected by Trypanosoma cruzi]. Bol Chil Parasitol 1978;33:2-7.

21. Schenone H, Carrasco J, Dedios F, et al. [Determination of the southern limit of dispersion of domiciliary Triatoma infestation and trypanosomal infection in Chile]. Bol Chil Parasitol 1961;16:59-62.

22. Fearon MA, Scalia V, Huang M, Dines I, Ndao M, Lagacé-Wiens P. A case of vertical transmission of Chagas disease contracted via blood transfusion in Canada. Can J Infect Dis Med Microbiol 2013;24:32-4.

23. Jackson Y, Myers C, Diana A, et al. Congenital transmission of Chagas disease in Latin American immigrants in Switzerland. Emerg Infect Dis 2009;15:601-3.

24. Munoz J, Coll O, Juncosa T, et al. Prevalence and vertical transmission of Trypanosoma cruzi infection among pregnant Latin American women attending 2 maternity clinics in Barcelona, Spain. Clin Infect Dis 2009;48:1736-40.

25. Revista da Sociedade Brasileira de Medicina Tropical International Colloquium. Congenital infection with Trypanosoma cruzi: From mechanisms of transmission to strategies for diagnosis and control. Rev Soc Bras Med Trop 2003;36:767-71.

26. Carlier Y, Torrico F, Sosa-Estani S, et al. Congenital Chagas disease: Recommendations for diagnosis, treatment and control of newborns, siblings and pregnant women. PLoS Negl Trop Dis 2011;5:e1250.

27. Bern C MSPHBL, Montgomery SP, Herwaldt BL, et al. Evaluation and treatment of Chagas disease in the United States: A systematic review. JAMA 2007;298:2171-81. 
28. Rodriques Coura J, de Castro SL. A critical review on Chagas disease chemotherapy. Mem Inst Oswaldo Cruz 2002;97:3-24.

29. Altcheh J, Biancardi M, Lapena A, Ballering G, Freilij H.

[Congenital Chagas disease: Experience in the Hospital de Ninos, Ricardo Gutierrez, Buenos Aires, Argentina]. Rev Soc Bras Med Trop 2005;38 Suppl 2:41-5.30.

30. Bern C. Antitrypanosomal therapy for chronic Chagas disease. N Engl J Med. 2011;364:2527-34.

31. Viotti R, Alarcón de Noya B, Araujo-Jorge T, et al; Latin American Network for Chagas Disease, NHEPACHA. Towards a paradigm shift in the treatment of chronic Chagas disease. Antimicrob Agents Chemother 2014;58:635-9.
32. Rassi A Jr, Rassi A, Marin-Neto JA. Chagas disease. Lancet 2010;375:1388-402.

33. Marin-Neto JA, Rassi A Jr, Avezum A Jr, et al. The BENEFIT trial: Testing the hypothesis that trypanocidal therapy is beneficial for patients with chronic Chagas heart disease. Mem Inst Oswaldo Cruz 2009;104(Suppl 1):319-24.

34. Molina I, Gómez i Prat J, Salvador F, et al. Randomized trial of posaconazole and benznidazole for chronic Chagas' disease. N Engl J Med 2014;370:1899-908. 


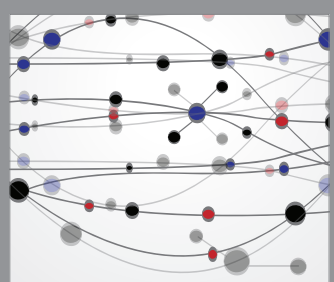

The Scientific World Journal
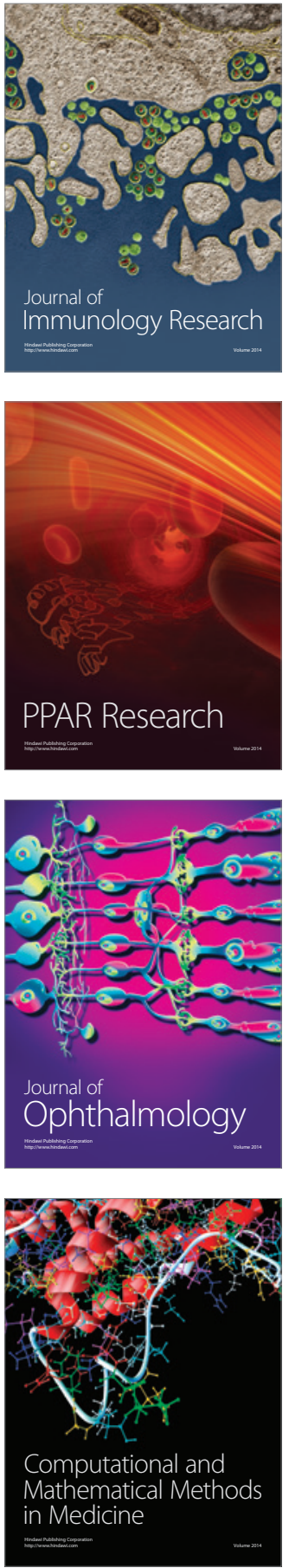

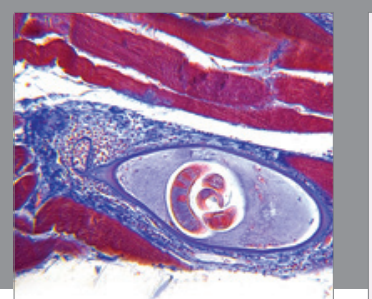

Gastroenterology Research and Practice

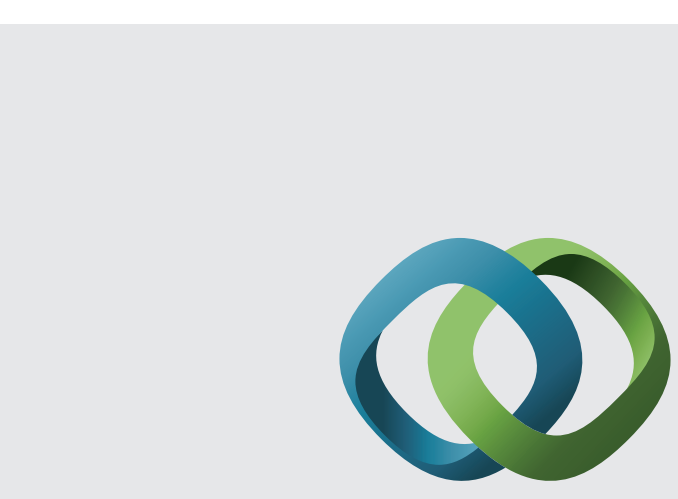

\section{Hindawi}

Submit your manuscripts at

http://www.hindawi.com
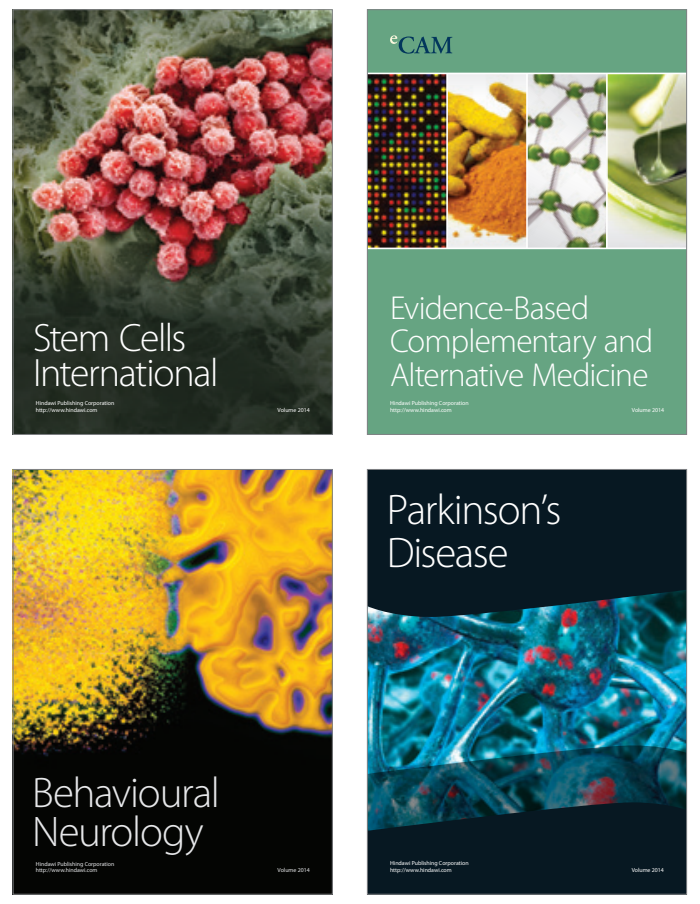
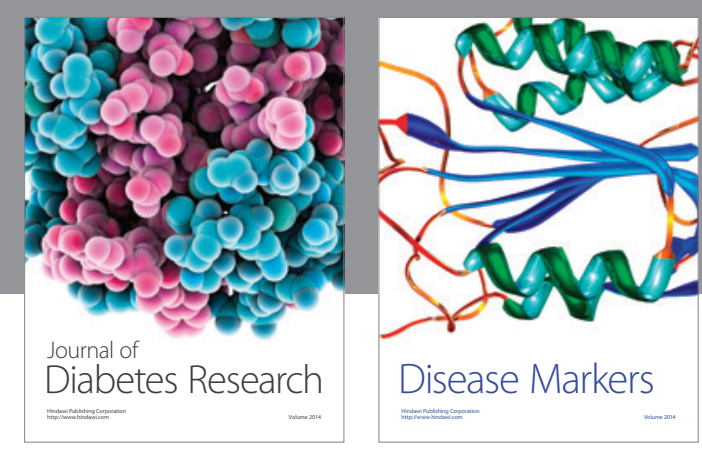

Disease Markers
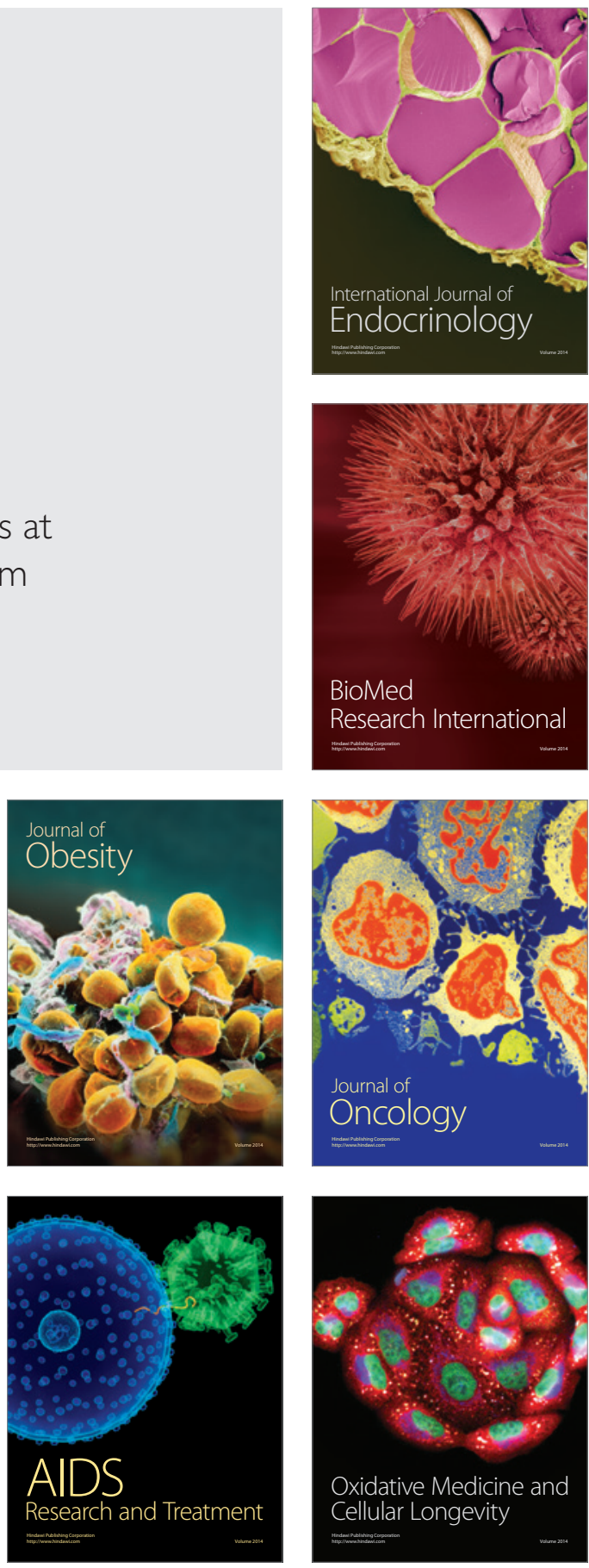